\title{
EFFECTS OF PRE-EXISTING FISSURES ON SURFACE MACRO-CRACK CHARACTERISTICS OF GRANITE SUBJECTED TO ELEVATED TEMPERATURES
}

\author{
Fei ZHAO ${ }^{1)}$, Qiang SUN ${ }^{2,3)}$ * and Xiaohua PAN ${ }^{4)}$
}

\author{
${ }^{1)}$ School of Resources and Geosciences, China University of Mining and Technology, Xuzhou, Jiangsu Province 221116, P.R. China \\ ${ }^{2)}$ Geological Research Institute for Coal Green Mining, Xi' an University of Science and Technology, Xi'an 710054, China \\ ${ }^{3)}$ College of geology and environment, Xi' an University of Science and Technology, Xi'an 710054, China \\ ${ }^{4)}$ School of Civil and Environmental Engineering, Nanyang Technological University, 639798. Singapore
}

*Corresponding author's e-mail: sunqiang04@cumt.edu.cn

\section{ARTICLE INFO \\ Article history: \\ Received 3 May 2019 \\ Accepted 25 September 2019 \\ Available online 21 November 2019}

\section{Keywords:}

Orthoclase granite

Macro-cracks

High temperature

Fractal dimension

\begin{abstract}
In order to study thermal macro-cracks on granite surface, experiments were conducted to heat orthoclase granite samples under $25-800^{\circ} \mathrm{C}$. This paper reports a method for evaluating thermal damage of rock by indexes of thermal macro-cracks characteristics, including the width of macro-cracks, the length of macro-cracks, the density of macro-cracks and fractal analysis of macro-cracks. The major findings are as follows: (1) As treatment temperature increases from $500{ }^{\circ} \mathrm{C}$ to $800{ }^{\circ} \mathrm{C}$, the average macro-crack width increases from 0.05 to $0.22 \mathrm{~mm}$. And the average macro-crack length increases from 34.36 to $771.86 \mathrm{~mm}$ at $600-800{ }^{\circ} \mathrm{C}$. In addition, the linear density is from 0.20 to $1.05 \mathrm{~mm}^{-1}$ and the surface density increases from 0.07 to $1.54 \mathrm{~mm} / \mathrm{mm}^{2}$ at $600-800{ }^{\circ} \mathrm{C}$. (2) The temperature has an important influence on the thermal fracture fractal of the granite surface. As treatment temperature increases from $600{ }^{\circ} \mathrm{C}$ to $800{ }^{\circ} \mathrm{C}$, the fractal dimension of macro-cracks changes from 0.47 to 1.43 . (3) $400-500{ }^{\circ} \mathrm{C}$ is the threshold temperature of the thermal macro-cracks generated on the granite surface and the high temperature causes the unpenetrated fissures connect with each other.
\end{abstract}

\section{NOTATION}

D Fractal dimension

$R^{2} \quad$ Coefficient of determination

$L_{w} \quad$ Width of macro-cracks $(\mathrm{mm})$

$L_{l} \quad$ Length of macro-cracks (mm)

$l \quad$ Length of pre-existing fissure $(20 \mathrm{~mm})$

$d \quad$ Width of pre-existing fissure $(2 \mathrm{~mm})$

$\lambda_{l} \quad$ Linear density of macro-cracks $\left(\mathrm{mm}^{-1}\right)$

$n \quad$ Number of macro-cracks at each line

$\lambda_{s} \quad$ Surface density of macro-cracks $\left(\mathrm{mm} / \mathrm{mm}^{2}\right)$

$a \quad$ Length of macro-crack area measured (mm)

$S \quad$ The selected area $\left(2500 \mathrm{~mm}^{2}\right)$

$\beta \quad$ Angle of fissures $\left(30^{\circ}, 45^{\circ}, 60^{\circ}\right)$

\section{INTRODUCTION}

In recent years, the effect of temperature on rock fracture has been a concern. There are many application fields, such as the development and utilization of geothermal resources (Ogino et al., 1999; Zhao et al., 2011; Rickard, 2019), excavations of storage sites of high radioactive nuclear waste underground (Hudson et al., 2001; Rutqvist et al., 2005; Emirov et al., 2013; Wang et al., 2015), geothermal reservoirs (Pearson et al., 1983; Ghassemi et al., 2007), oil production and storage (Shafiei and Dusseault, 2013) and so on (Smith and Pells, 2008; Vasconcelos et al., 2008; Ozguven and Ozcelik, 2013; Tang et al., 2016). Further study indicates that fracture initial and progress induced by high temperature were important to the stability of the rock mass (Fredrich and Wong, 1986; Meredith et al., 2001; Nasseri et al., 2009; Freire-Lista et al., 2015). Extensive experiments have been carried out to investigate the failure mechanism of rock specimens in laboratory scale subjected to high temperature, especially the granite which is one of the various rock types encountered when geothermal resources development (David et al., 1999; Yoshitaka et al., 2010; Vázquez et al., 2015; Gautam et al., 2016). And many authors have done thermal tests in building stones and these thermal tests generated fissures (Wang et al., 2015; Sun et al., 2015; Freire-Lista et al., 2016; Zhu et al., 2016; Murru et al., 2018). These studies proved that the macroscopic swelling strain is the combined results of local free swelling strains and additional mechanical strains induced by these interactions. The development of new micro-cracks indicted high temperature and thermal cycles may lead to the development of new micro-cracks or growth of preexisting micro-cracks within building stone. And they also proposed that pre-existing micro-cracks coalesced and generated further micro-cracking as decay progressed, ultimately impacting the petrophysical properties and hence the quality and durability of the material.

In fact, there are some studies which used crack density and fractal dimension to characterize the development degree of rock cracks. Fredrich and 


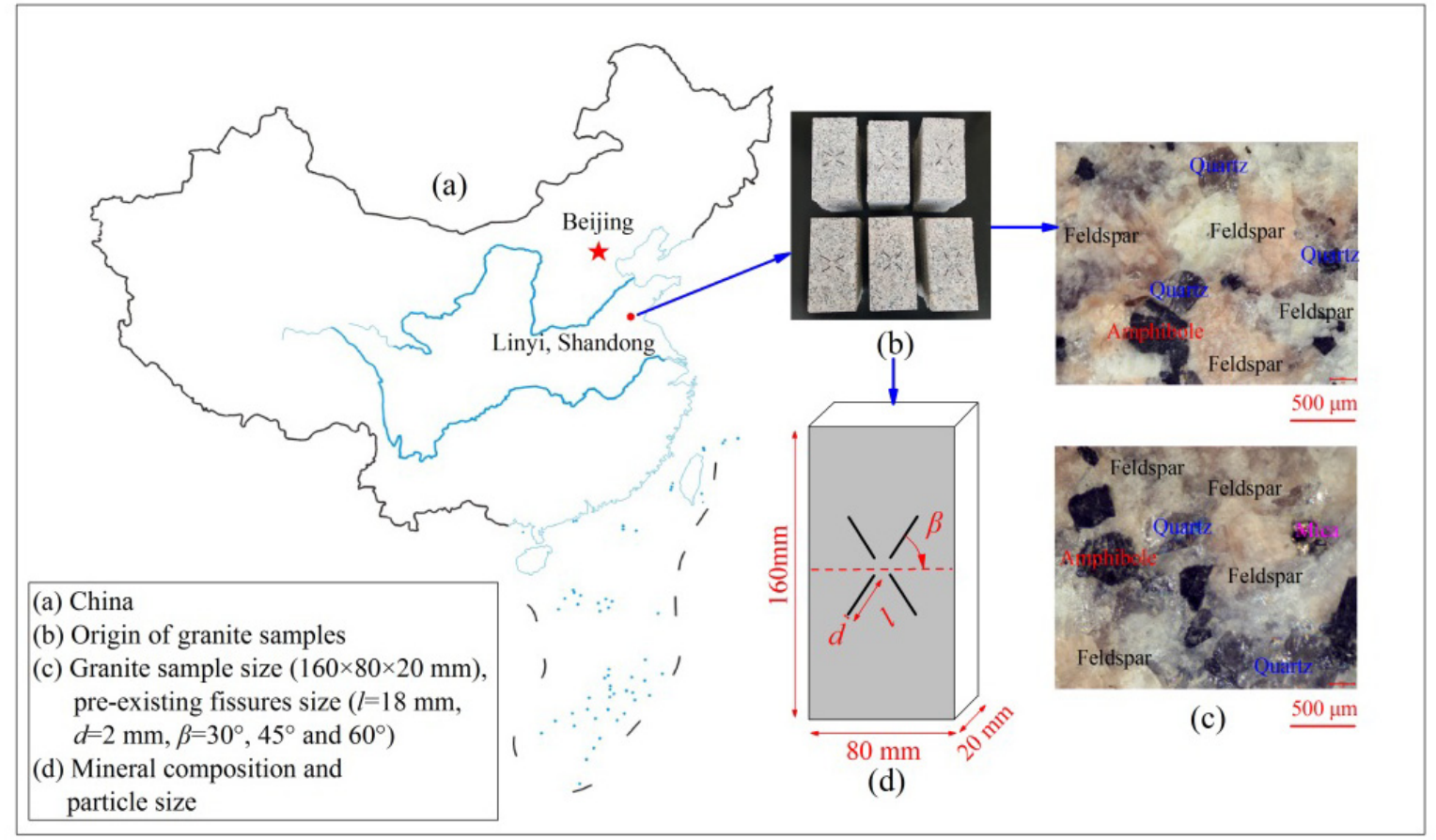

Fig. 1 Granite samples.

Wong (1986), Nasseri et al. (2007 and 2009) and Griffiths et al. (2017) studied and calculated microcrack densities of heated granite. There are also studies which use numerical image analysis to calculate crack geometries (Arena et al., 2014; Delle Piane et al., 2015; Griffiths et al., 2017; Wang et al., 2017). Wang et al. (2017) also perform a fractal analysis of cracking patterns. However, there were relatively few studies on surface macro-cracks of granite samples with internal defects after or under high temperature treatment. In particular, there are few scientific researches on the damage evolution law of cracks with different defects at different temperatures. In view of the shortcomings of the above researches, this paper fully considers the effect of defects on the failure of granite. The granite surface cracks were analyzed by cracks density and fractal dimension method. Based on the experimental results, some conclusions corresponding to the relationship among surface cracks, and temperature, distribution characteristics of macro-cracks and laws of macrocrack expansion were obtained that might be applicable as methods to evaluate the thermal damage and strength characteristics of granite (Zhao, 2016; Mardoukhi et al., 2017).

\section{METHODS AND MATERIALS}

\subsection{SAMPLE PREPARATION}

Granite samples that were tested were cut from a block, which were collected from Linyi, Shandong, China (see Fig. 1(a) and (b)). The x-ray diffraction analysis showed that the primary minerals are feldspar (58.4 \%), quartz (32.0\%), amphibole $(6.1 \%)$, mica $(3.4 \%)$ and other small amounts of minerals, which can be classified as orthoclase granite. Most of the mineral particles of the granite have a grain size between 1 and $10 \mathrm{~mm}$ in diameter (see Fig. 1(c)). The samples were cut into plate shape (i.e. $160 \times 80 \times 20 \mathrm{~mm})$ with three types of fissures (i.e. $\beta=30^{\circ}, 45^{\circ}, 60^{\circ}$ ) (see Fig. $1(\mathrm{~d})$ ). The total number of experimental granite samples is 48 . The specimens were heated seven different temperature levels (i.e. $100,300,400,500,600,700$ and $800{ }^{\circ} \mathrm{C}$, respectively) in furnace (type KSL-1700X) at a rate of $10{ }^{\circ} \mathrm{C} / \mathrm{min}$ and maintained for $1 \mathrm{~h}$. Then, the samples were cooled to room temperature in air condition.

\subsection{WIDTH MEASUREMENT OF SURFACE MACRO- CRACKS}

The surface of granite sample heated by high temperature is scanned, and all macro-cracks are extracted. The surface macro-cracks of granite are observed and recorded by electron microscopy (type SupereyesTM). The width of macro-cracks is measured according to the scale in the electron microscopic image, and the average width of multiple cracks is measured (see Fig. 2). (Notation: Under the electron microscope, the minimum width of macrocracks we can measure is $0.05 \mathrm{~mm}$ at $500{ }^{\circ} \mathrm{C}$. The values of specimens subjected to $400{ }^{\circ} \mathrm{C}$ were therefore recorded as $0 \mathrm{~mm}$.).

\subsection{CALCULATION OF SURFACE MACRO-CRACKS DENSITY}

The obtained macro-crack images were binarized with matlab. An area $(50 \times 50 \mathrm{~mm})$ marked with red rectangular (see Fig. 3) was selected and used to have a statistical analysis of the macro-cracks in numbers and geometries. The macro-crack total length $L_{l}$ of granite samples with heated same temperature was measured (Notation: Under the electron microscope, the minimum total length of macro-cracks we can measure is $5.5 \mathrm{~mm}$ at $500{ }^{\circ} \mathrm{C}$. The values of specimens subjected to $400{ }^{\circ} \mathrm{C}$ were therefore recorded as $0 \mathrm{~mm}$.). The linear density, $\lambda_{l}$ and the surface density, $\lambda_{S}$, can be calculated by Eq. (1) and 


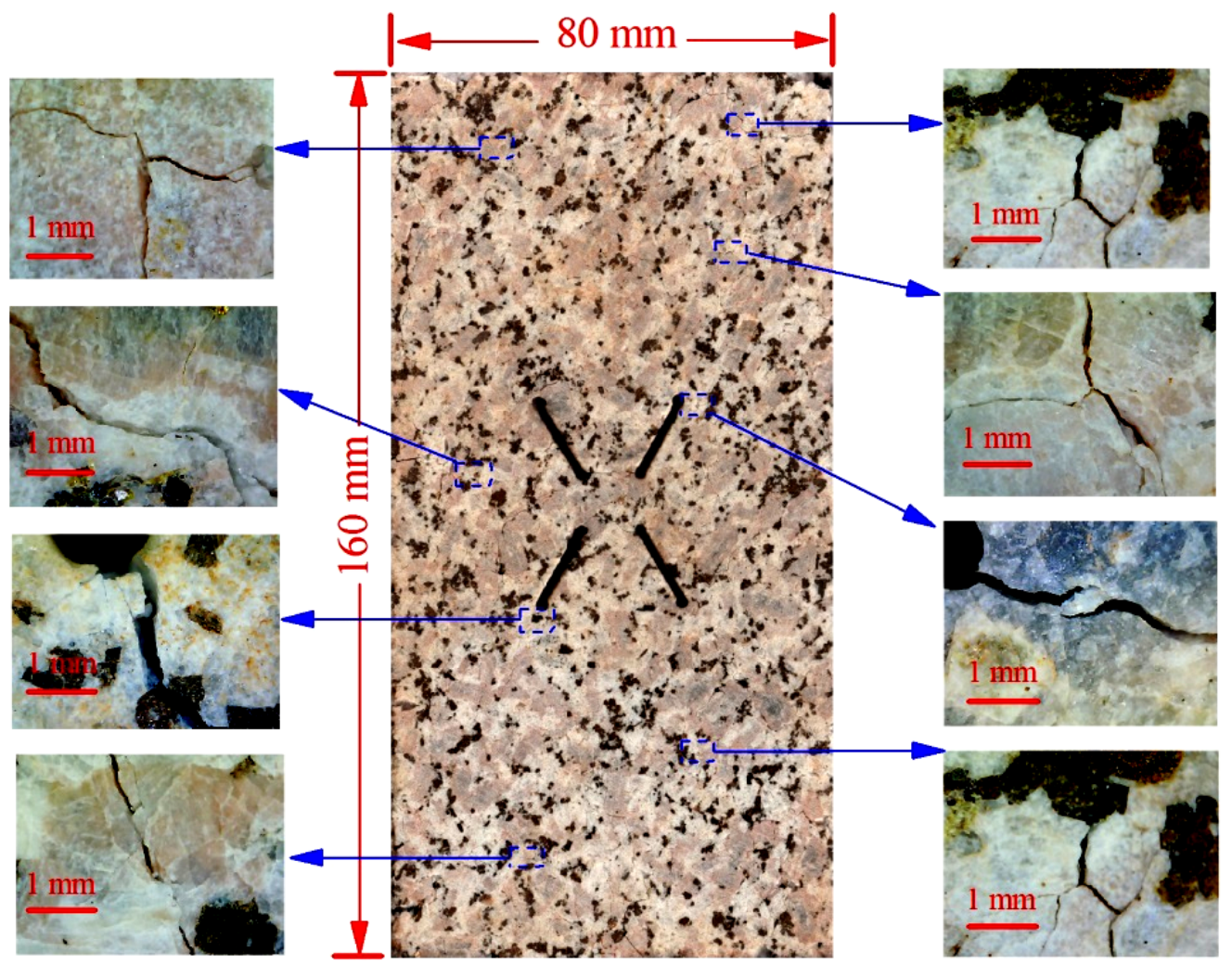
(a) Micrograph
(b) Heated granite sample
(c) Micrograph

Fig. 2 Width measurement of surface macro-cracks.

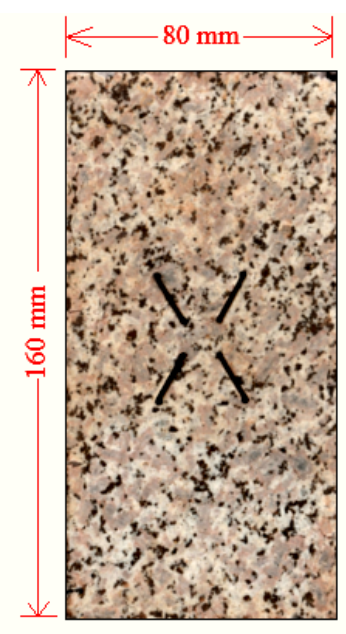

(a) Heated granite sample

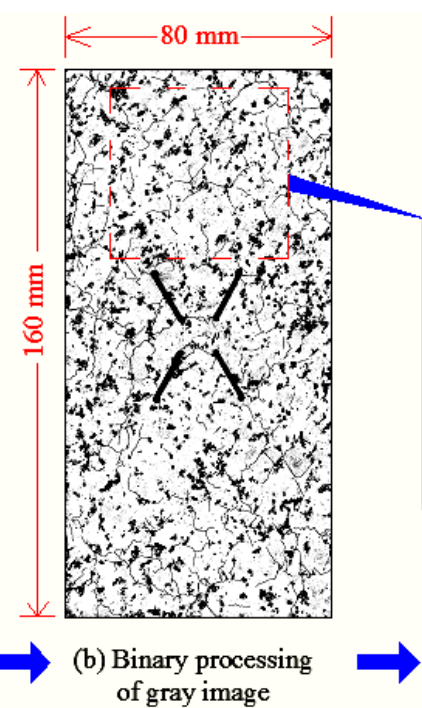

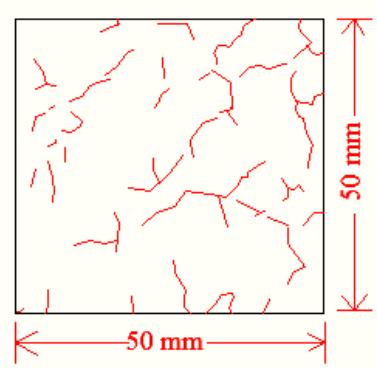

(c) The area $(50 \times 50 \mathrm{~mm}) \Rightarrow$ (d) Measurement and calculation of total macro-cracks length

Fig. 3 Measurement and calculation of total macro-cracks length.

Eq. (2), respectively (Nasseri et al., 2007 and 2009).

$\lambda_{l}=\frac{n}{a}$

$\lambda_{S}=\frac{L_{l}}{S}$

Where, $n$ is number of macro-cracks at each line; $a$ are length of macro-crack area measured $(\mathrm{mm}) ; \lambda_{l}$ is linear density of macro-cracks $\left(\mathrm{mm}^{-1}\right) ; L_{l}$ is length of macrocracks $(\mathrm{mm}) ; S$ is the selected area $\left(2500 \mathrm{~mm}^{2}\right) ; \lambda_{s}$ is surface density of macro-cracks $\left(\mathrm{mm} / \mathrm{mm}^{2}\right)$.

\subsection{CALCULATION OF SURFACE MACRO-CRACKS FRACTAL DIMENSION}

Macro-cracks image extracted from Figure 3 was subdivided again, that was, the selected fissure region was segmented continuously (see Fig. 4). After measuring the total length of macro cracks, the fractal dimension of macro-cracks was calculated by Eq. (3) (Underwood, 1967; Velde, 1999; Colina and Acker, 2000; Vogel et al., 2005 a and b). The fractal dimensions of macro-cracks of granite with the same temperature treatment were averaged. 


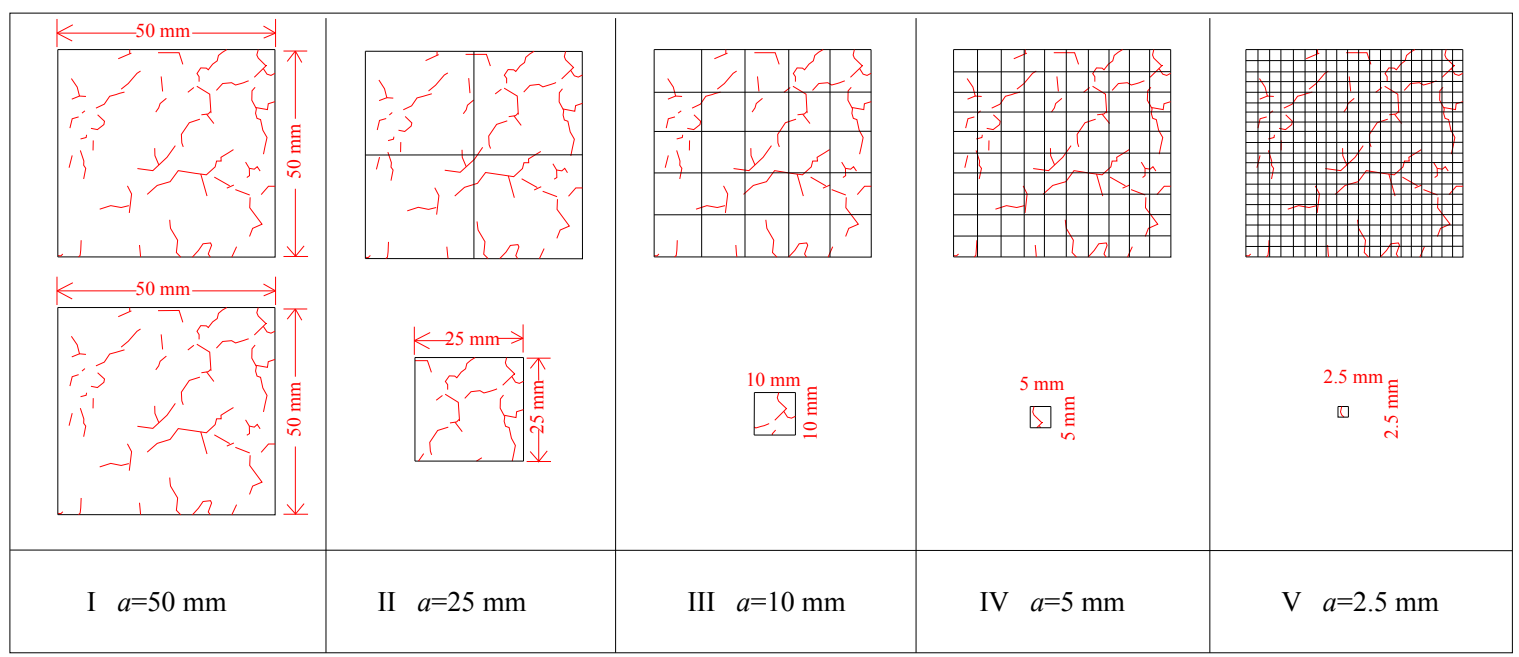

Fig. 4 Calculation of macro-cracks fractal dimension.

Table 1 The surface macro-crack indices of granite after elevated temperature treatment.

\begin{tabular}{cccccccc}
\hline $\begin{array}{c}\text { Temperature } \\
\left({ }^{\circ} \mathrm{C}\right)\end{array}$ & $\beta\left(^{\circ}\right)$ & $D$ & $R^{2}$ & $\begin{array}{c}L_{w} \\
(\mathrm{~mm})\end{array}$ & $\begin{array}{c}L_{l} \\
(\mathrm{~mm})\end{array}$ & $\begin{array}{c}\lambda_{l} \\
\left(\mathrm{~mm}^{-1}\right)\end{array}$ & $\begin{array}{c}\lambda_{s} \\
\left(\mathrm{~mm} / \mathrm{mm}^{2}\right)\end{array}$ \\
\hline \multirow{3}{*}{500} & 30 & - & - & 0.06 & 6.12 & 0.00 & 0.00 \\
& 45 & - & - & 0.06 & 5.28 & 0.00 & 0.00 \\
& 60 & - & - & 0.05 & 5.10 & 0.00 & 0.00 \\
\hline \multirow{3}{*}{600} & 30 & 0.47 & 0.895 & 0.09 & 31.38 & 0.23 & 0.06 \\
& 45 & 0.45 & 0.760 & 0.08 & 36.83 & 0.20 & 0.07 \\
& 60 & 0.50 & 0.678 & 0.08 & 34.86 & 0.17 & 0.07 \\
\hline \multirow{3}{*}{700} & 30 & 0.58 & 0.989 & 0.14 & 94.13 & 0.43 & 0.19 \\
& 45 & 0.61 & 0.929 & 0.14 & 79.26 & 0.33 & 0.16 \\
& 60 & 0.62 & 0.947 & 0.14 & 70.88 & 0.30 & 0.14 \\
\hline \multirow{3}{*}{800} & 30 & 1.40 & 0.988 & 0.22 & 966.11 & 1.28 & 1.93 \\
& 45 & 1.45 & 0.985 & 0.22 & 696.94 & 0.97 & 1.39 \\
& 60 & 1.45 & 0.982 & 0.22 & 652.53 & 0.90 & 1.31 \\
\hline
\end{tabular}

$D=\frac{\log L_{l}}{\log a}$

Where, $L_{l}$ is length of macro-cracks $(\mathrm{mm}) ; a$ are length of macro-crack area measured $(\mathrm{mm}) ; D$ is fractal dimension.

\section{RESULTS}

\subsection{SURFACE MACRO-CRACKS IN RED RECTANGULAR AREA}

Table 1 presents the statistical results of granite specimens with different flaw inclination angles after elevated temperature treatment in red rectangular area the fractal dimension, $D$, coefficient of determination, $R^{2}$, the width of macro-cracks, $L_{w}$, the total length of macro-cracks, $L_{l}$, the linear density, $\lambda_{l}$, the surface density, $\lambda_{s}$.

Under the electron microscope, no macro-cracks were found at $400{ }^{\circ} \mathrm{C}$. Therefore, the values of specimens subjected to $400{ }^{\circ} \mathrm{C}$ were recorded as $0 \mathrm{~mm}$. At $500{ }^{\circ} \mathrm{C}$, there are a few macro-cracks on the surface of granite, and mostly around prefabricated fissures and edge of slate granite. With increase of temperature, the surface macro-cracks of granite develop continuously. What's more, macro-crack coalescence phenomenon was observed when the specimens subjected to $700{ }^{\circ} \mathrm{C}$, which induced the formation of the network macro-cracks as temperature reached at $800{ }^{\circ} \mathrm{C}$ (see Fig. 5).

\subsection{THE WIDTH OF SURFACE MACRO-CRACKS}

Figure 6 indicates that the width of surface macro-cracks increased as temperature increased, especially when the temperature exceeded $600{ }^{\circ} \mathrm{C}$. Due to the minimum width of surface macro-cracks that could be measured was $0.05 \mathrm{~mm}$, the values of specimens subjected to $400{ }^{\circ} \mathrm{C}$ were therefore recorded as $0 \mathrm{~mm}$. Table 1 shows that the widths of the surface macro-cracks of specimens subjected to $500{ }^{\circ} \mathrm{C}$ with $\beta=30^{\circ}, 45^{\circ}$ and $60^{\circ}$ were $0.06,0.06$ and $0.05 \mathrm{~mm}$, respectively, whose mean value was $0.06 \mathrm{~mm}$. Following the same calculating procedure, the mean values of the widths of the surface macrocracks of specimens subjected to $600{ }^{\circ} \mathrm{C}, 700{ }^{\circ} \mathrm{C}$ and $800{ }^{\circ} \mathrm{C}$ were $0.08,0.14$ and $0.22 \mathrm{~mm}$, respectively, which were in ascending order.

\subsection{THE DENSITY OF SURFACE MACRO-CRACKS}

Figure 7 shows that the linear density and surface density of the surface macro- cracks both 

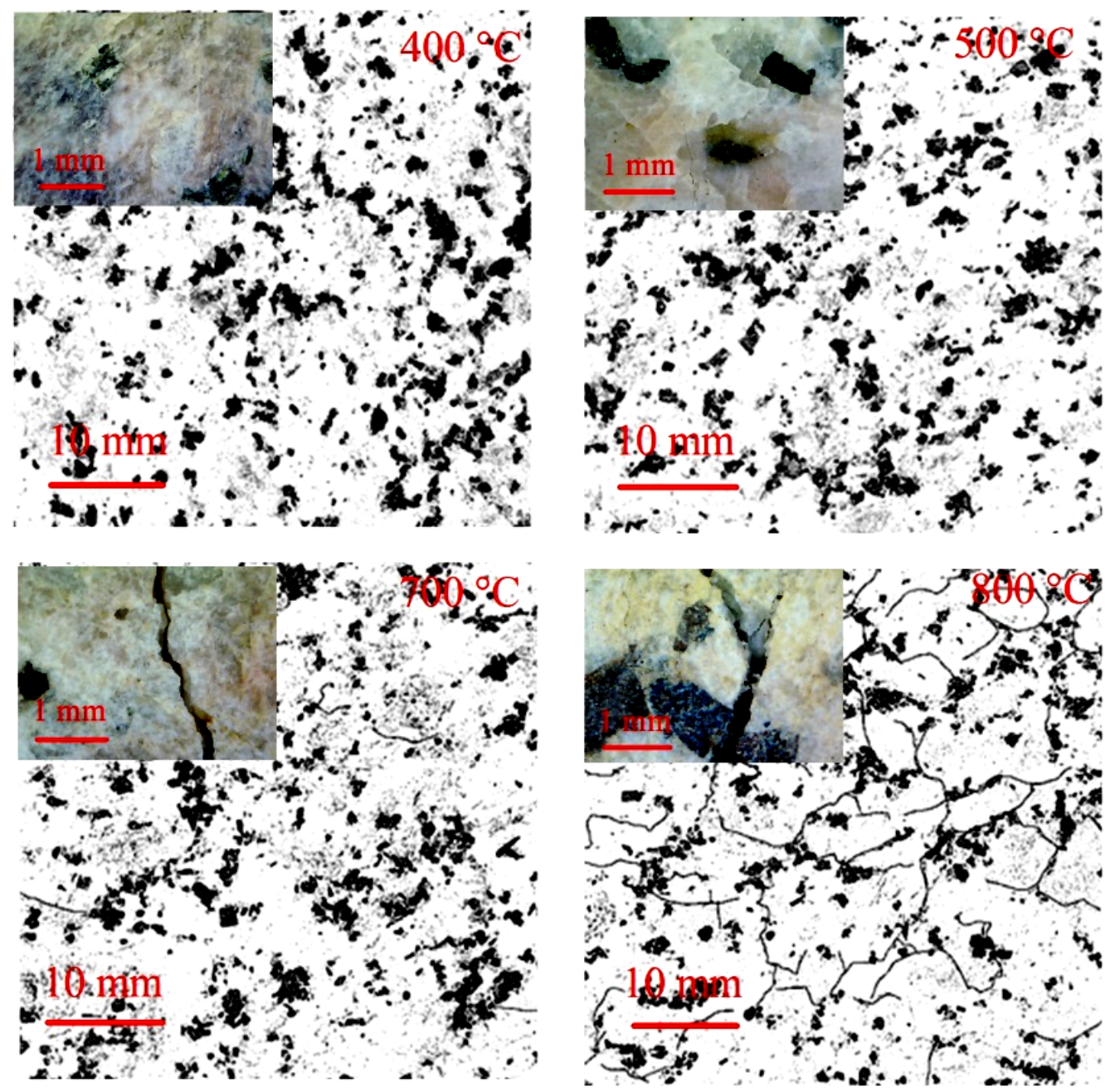

Fig. 5 Surface macro-cracks of granite treated by different temperatures.

increased as temperature increased, especially when the temperature exceeded $700{ }^{\circ} \mathrm{C}$. Due to the limitation of measure equipment, the linear density and surface density of specimens subjected to $400{ }^{\circ} \mathrm{C}$, values were both recorded as 0 . Table 1 shows that the liner density of the surface macro-cracks of specimens subjected to $600{ }^{\circ} \mathrm{C}$ with $\beta=30^{\circ}, 45^{\circ}$ and $60^{\circ}$ were $0.23,0.20$ and $0.17 \mathrm{~mm}^{-1}$, respectively, corresponding mean value was $0.20 \mathrm{~mm}^{-1}$. As temperature increased to $700{ }^{\circ} \mathrm{C}$ and $800{ }^{\circ} \mathrm{C}$, the mean values of linear density significantly increased to 0.35 and $1.05 \mathrm{~mm}^{-1}$. Following the same comparison process, the mean values of the surface density of the surface macrocracks of specimens subjected to $600{ }^{\circ} \mathrm{C}, 700{ }^{\circ} \mathrm{C}$ and $800{ }^{\circ} \mathrm{C}$ were $0.07, \quad 0.17$ and $1.54 \mathrm{~mm} / \mathrm{mm}^{2}$, respectively, which were in ascending order.

\subsection{SURFACE MACRO-CRACK FRACTAL DIMENSION}

Figure 8 and Table 1 show that, with elevated treatment temperature, the more macro-cracks are developed, the greater the fractal dimension $D$ is calculated. When temperature is $600{ }^{\circ} \mathrm{C}$, the fractal dimension is 0.47 (as shown in Fig. 8(a)). The fractal dimension is 0.60 at $700{ }^{\circ} \mathrm{C}$ (see Fig. 8(b)). It can also be seen that fractal dimension of granite macro-cracks increases sharply after $700{ }^{\circ} \mathrm{C}$. The fractal dimension increases to 1.43 at $800{ }^{\circ} \mathrm{C}$ (as shown in Fig. 8(c)).
Figure $8(d)$ is the average fractal dimension of granite with three types of pre-existing fissures. It can be clearly seen from it that the average fractal dimension of macro-cracks on the surface of granite increases with different treatment temperatures.

\section{DISCUSSION}

Through analyzing the previous research results, this increase in macro-crack width, density and fractal dimension of heated granite is mainly caused by the variation of internal minerals and structure induced by heat (Gomez-Heras et al., 2009). According to the previous research results (Nasseri et al., 2007 and 2009), Width and density of macro-cracks are often used to evaluate rock damage. The evolution of intragranular (IG) and grain boundary micro-crack (GB) widths for Westerly granite heated by $25-850{ }^{\circ} \mathrm{C}$ has a consistent upward trend with our study (as shown in Fig. 9, Nasseri et al., 2007). The micro-cracks density of granite increases with increase of temperature and changes sharply after $600{ }^{\circ} \mathrm{C}$, which has a consistent upward trend with macro-cracks density in our study (as shown in Fig. 10, Nasseri et al., 2009 and Griffiths et al., 2017).

In this study, granite is composed of minerals with different thermal expansion coefficients. Due to significant amounts of thermally induced damage in the form of grain-grain boundary micro-cracking, 


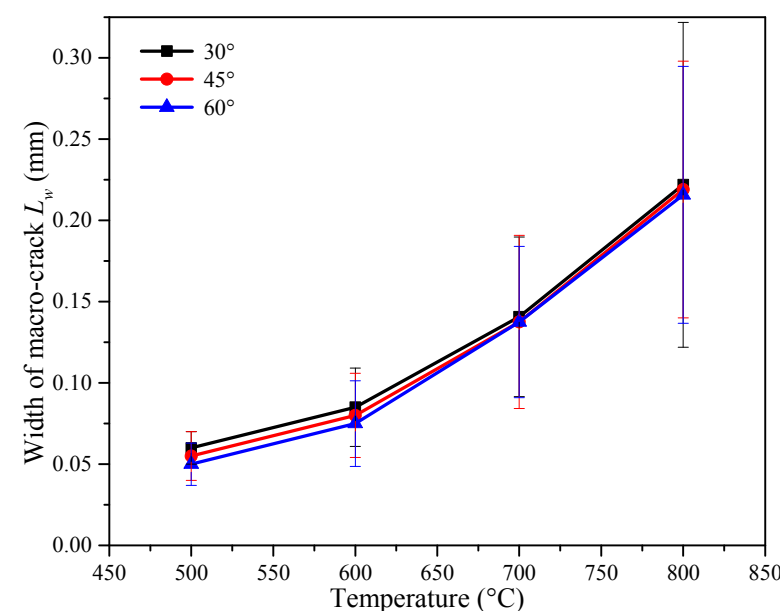

Fig. 6 Surface macro-crack width of granite after elevated temperature treatment.

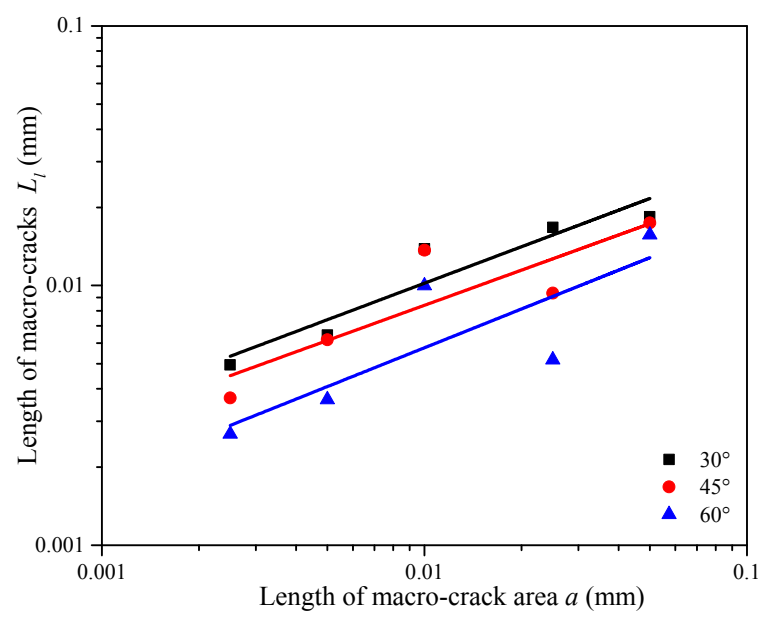

(a)

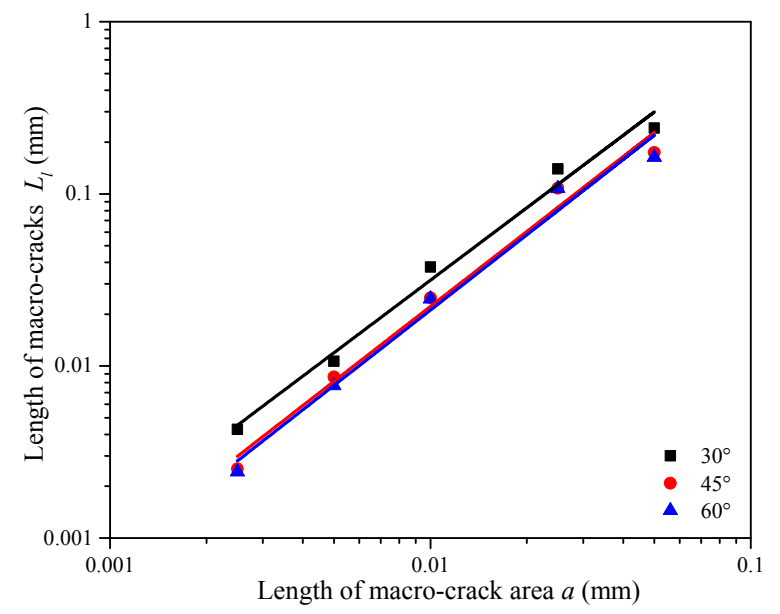

(c)

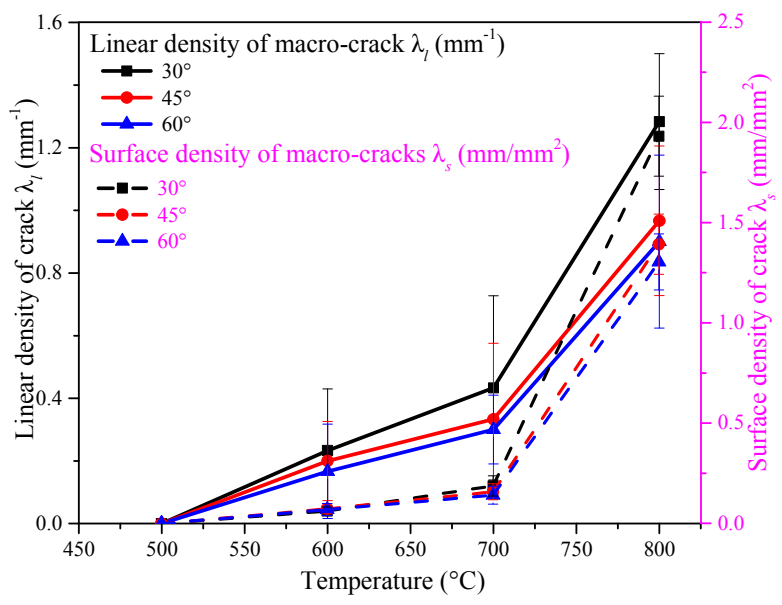

Fig. 7 Linear density and surface density of surface macro-cracks of granite after elevated temperature treatment.

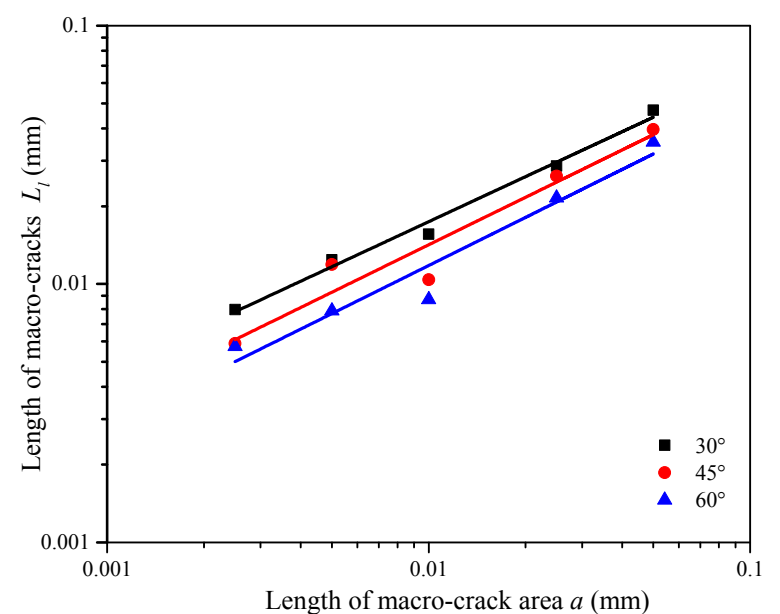

(b)

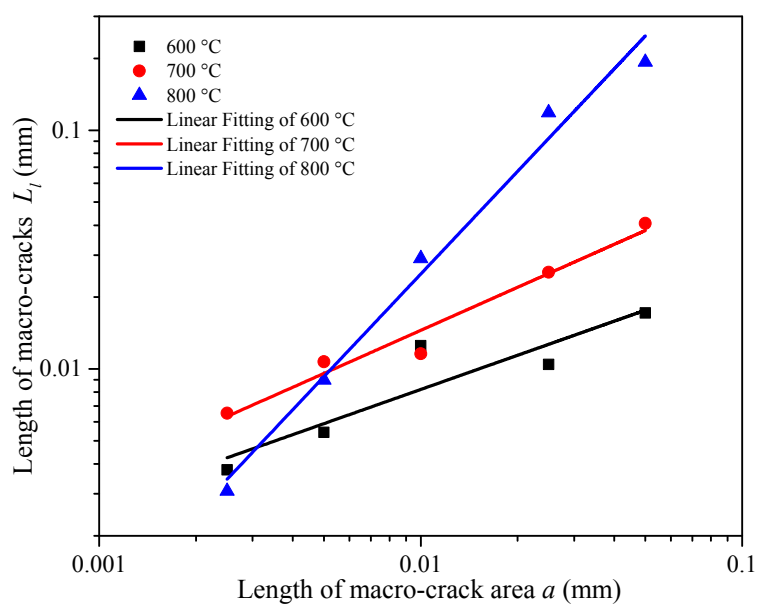

(d)

Fig. 8 Fractal dimension of surface macro-cracks of granite after elevated temperature treatment. (a) $600{ }^{\circ} \mathrm{C}$; (b) $700{ }^{\circ} \mathrm{C}$; (c) $800{ }^{\circ} \mathrm{C}$; (d) The average fractal dimension of granite with three types of pre-existing fissures at each temperature.

mineral particles in granite samples will expand unevenly with increase of temperature (Liu and $\mathrm{Xu}$, 2014; Freire-Lista et al., 2015; Sun et al., 2016; Freire-Lista et al., 2016; Zhang et al., 2016). When thermal stress reaches or exceeds the local strength, due to differences in the expansion coefficients between constituent minerals or even within the same mineral, granite is unable to adapt quickly enough to accommodate the strain generated during cooling, and the connection between the mineral particles would be destroyed (Hall, 1999; Hale and Shakoor, 2003; Yoshitaka et al., 2010; Yavuz, 2011; Demirdag, 2013; 
Hall andThorn, 2014). For example, due to the quick expansion with increasing temperature and the transformation of quartz from alpha quartz to beta quartz at about $573{ }^{\circ} \mathrm{C}$ and atmospheric conditions (Somerton and Boozer, 1961; Bauer and Handin, 1983), internal defects would grow and change the internal properties of granite, and the thermal expansion of granite would increase and change sharply about $550-600{ }^{\circ} \mathrm{C}$ (as shown in Figs. 9, 10 and 11, Bauer and Handin, 1983; Alm, 1985; iu and Xu, 2014; Sun et al., 2015; Sun et al., 2016). Therefore, the macro-cracks will appear and expend so that the macro-crack width and density will increase. In addition, there are many studies on dry cracks of clay by using fractal dimension of macro-cracks (Velde, 1999; Colina and Acker, 2000; Vogel et al., 2005 $a$ and b), which can describe well the relation of cracks and dry days. However, few studies about macro-cracks of heated rocks have been analyzed by using fractal dimension. In this study, we would use fractal dimension $D$ to describe the development characteristics of macro-cracks with different temperature (as shown in Fig. 12).

Thermal macro-cracks expanded on the basis of pre-existing fissures during high temperature (as shown in Fig. 13). With elevated temperature treatment, cracks expand along specific directions with a certain angle between macro-cracks and preexisting fissures. And numbers of granite surface macro-cracks distributing around pre-existing fissures increase constantly. At the end of pre-existing fissures, macro-cracks gradually develop until they transfix with each other as temperature continues to rise (Nasseri et al., 2009; Wang et al., 2015; Sun et al., 2015; Freire-Lista et al., 2015 and 2016).

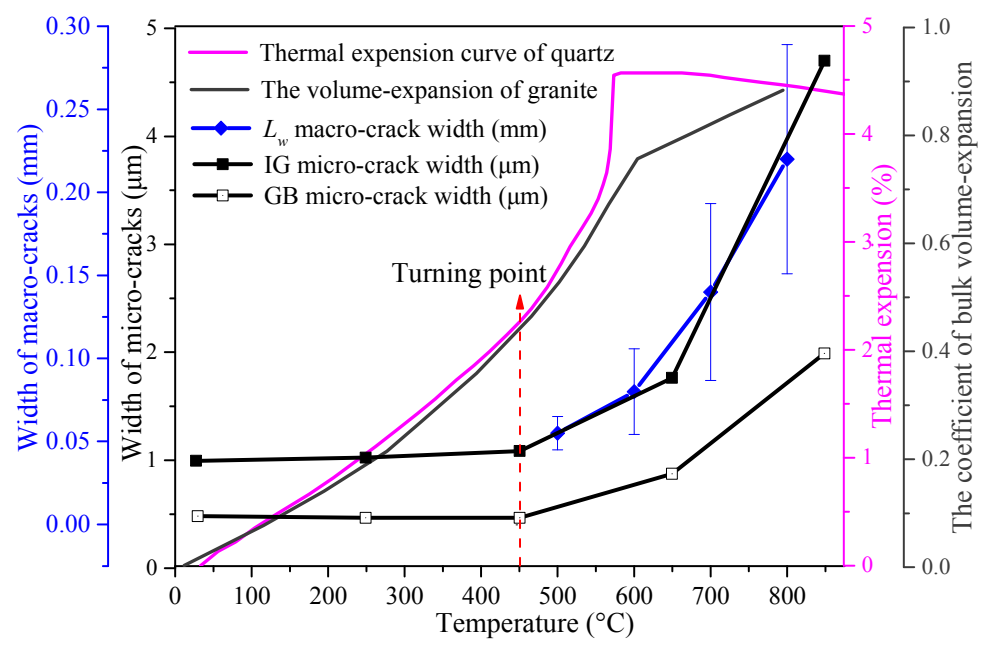

Fig. 9 Average macro-crack width of granite after elevated temperature treatment (The thermal expansion data of quartz from Somerton and Boozer (1961); The coefficient of bulk volume-expansion of granite from Bauer and Handin (1983); The data of evolution of intra-granular (IG) and grain boundary micro-crack (GB) widths for Westerly granite from Nasseri et al. (2007)).

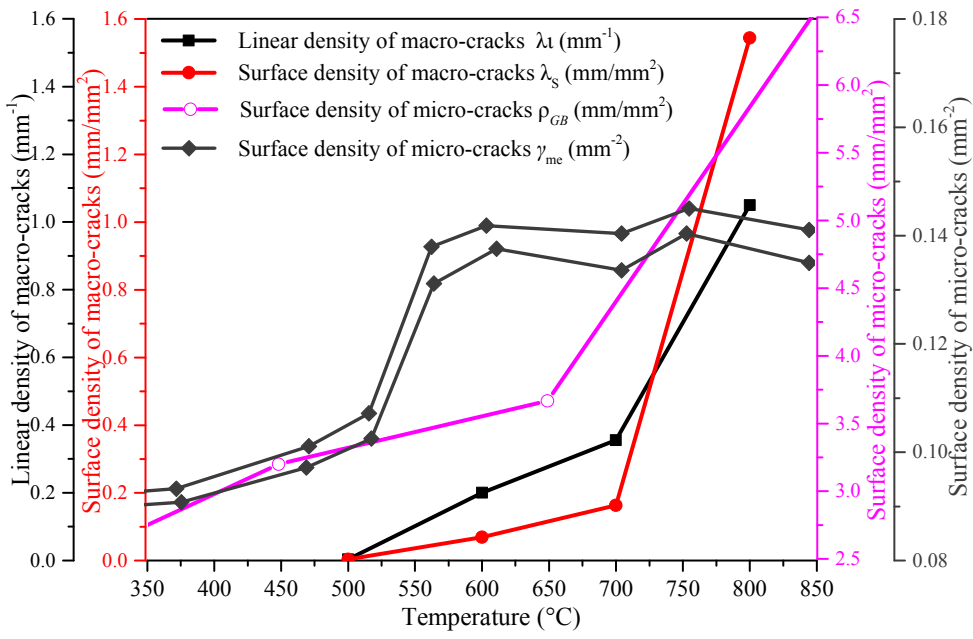

Fig. 10 Surface macro-crack density of granite after elevated temperature treatment (The micro-cracks density data $\rho_{\mathrm{GB}}$ of granite from: Nasseri et al. (2009); The micro-cracks density data $\gamma_{\mathrm{me}}$ of granite from: Griffiths et al. (2017)). 

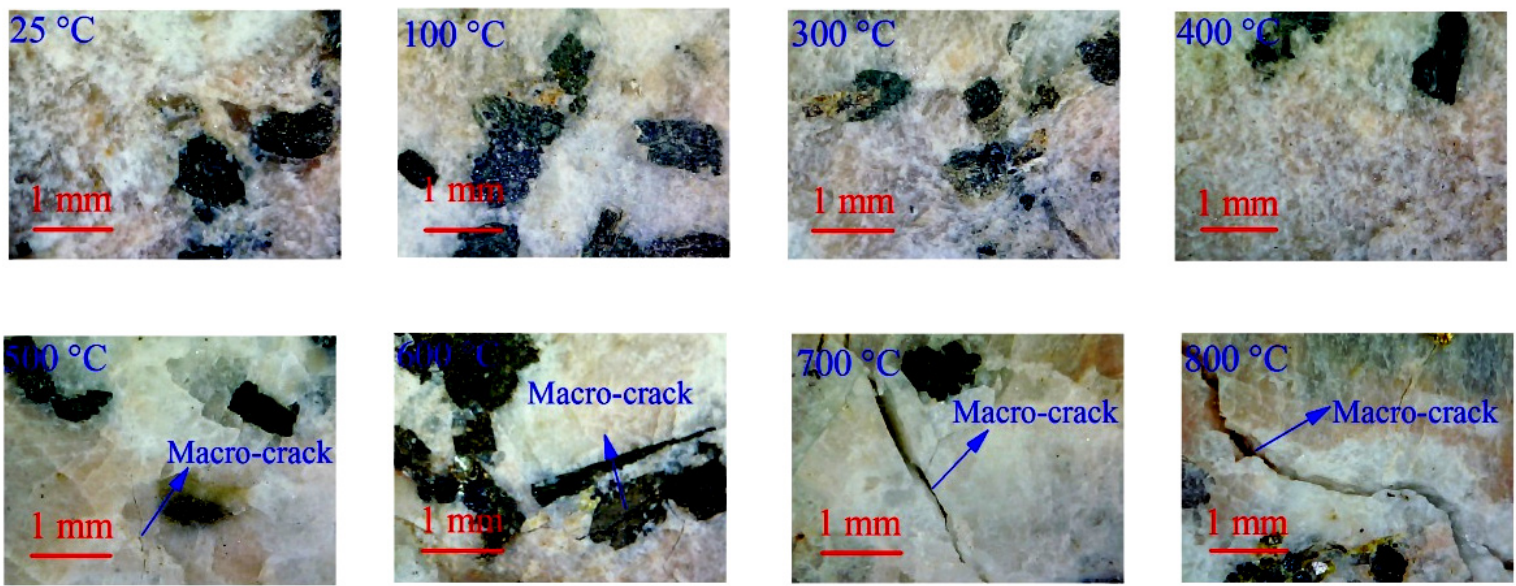

Fig. 11 Surface macro-cracks of granite after elevated temperature treatment.

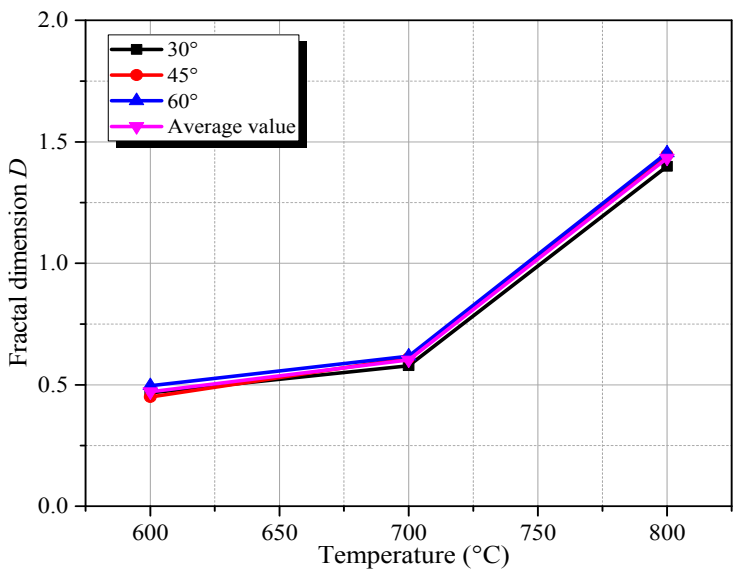

Fig. 12 The relations between treatment temperature and fractal dimension.
In summary, this increase in macro-cracks width, density and fractal dimension of heated granite is caused by mineral particles with different thermal expansion coefficients and thermo-elastic characteristics. High temperature would lead to inhomogeneous thermal expansion of mineral particles or phase transition of some mineralogical components, generating internal stress and macrocracks in granite. In addition, pre-existing fissures are more likely to lead to the further development of internal fissures in granite. At the same time, it can be seen from the above analysis that different preexisting fissures angles have little effect on macrocrack width, density and fractal characteristics.

\section{CONCLUSION}

It can be inferred that in this study, due to different thermal expansibility for minerals in granite, the surface of granite will occur to crack due to thermal damage in the process of high temperature.
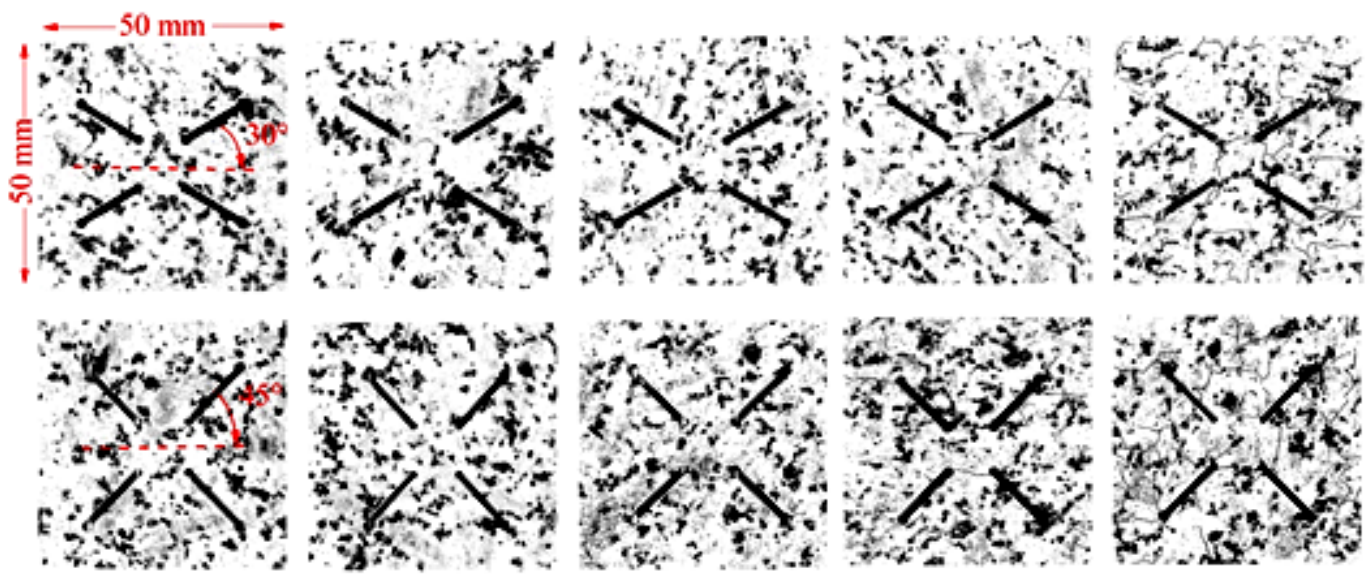

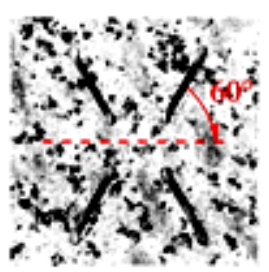

$400^{\circ} \mathrm{C}$

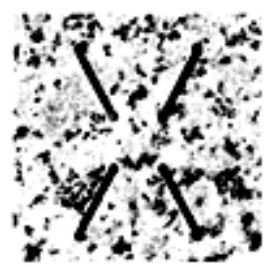

$500^{\circ} \mathrm{C}$

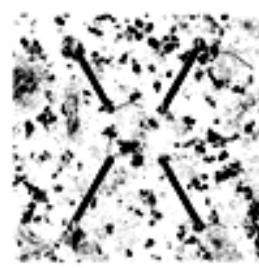

$600^{\circ} \mathrm{C}$

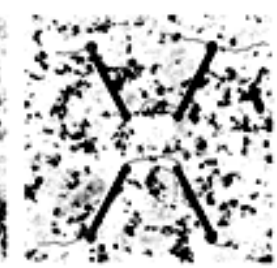

$700^{\circ} \mathrm{C}$

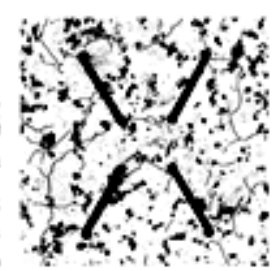

$800{ }^{\circ} \mathrm{C}$

Fig. 13 Distribution of surface macro-cracks of granite specimens with different flaw inclination angles after elevated temperature treated in pre-existing fissure area. 
Macro-cracks patterns on surface granite can be characterized by a few parameters: width of macrocracks $L_{w}$, length of macro-cracks $L_{l}$, surface macrocracks density $\lambda_{s}$, linear macro-cracks density $\lambda_{l}$, fractal dimensions $D$ and relative treatment temperature. This greatly facilitates the comparison of macro-crack extension in different temperature. The major findings are as follows:

1. As treatment temperature increases from $500{ }^{\circ} \mathrm{C}$ to $800{ }^{\circ} \mathrm{C}$, the average macro-crack width $L_{w}$ increases from 0.05 to $0.22 \mathrm{~mm}$. And the average macro-crack length $L_{l}$ increases from 34.36 to $771.86 \mathrm{~mm}$ at $600-800{ }^{\circ} \mathrm{C}$. In addition, with temperature increasing from $600-800{ }^{\circ} \mathrm{C}$, the linear density $\lambda_{l}$ is from 0.20 to $1.05 \mathrm{~mm}^{-1}$, and the surface density $\lambda_{s}$ increases from 0.07 to $1.54 \mathrm{~mm} / \mathrm{mm}^{2}$.

2. From the experimental results, we can see that the temperature has an important influence on the thermal fracture fractal of the granite surface. The higher the temperature, the greater the fractal value of the thermal macro-cracks. As treatment temperature increases from $600{ }^{\circ} \mathrm{C}$ to $800{ }^{\circ} \mathrm{C}$, the fractal dimension $D$ of macro-cracks changes from 0.47 to 1.43 .

3. $400-500{ }^{\circ} \mathrm{C}$ is the threshold temperature of the thermal macro-cracks generated on the granite surface, and the thermal macro-cracks first appears around the precast fissure, and the high temperature causes the unpenetrated fissures connect with each other.

\section{ACKNOWLEDGMENTS}

This research was supported by "National Natural Science Foundation of China" (No. 41672279 and No. 41874113) and the Priority Academic Program Development of Jiangsu Higher Education Institutions. We would also like to thank the technicians who helped us during the experiment and the anonymous reviewer for the constructive comments.

\section{REFERENCES}

Alm, O.: 1985, The influence of micro crack density on the elastic and fracture mechanical properties of stropa granite. Phys. Earth Planet. Inter., 40(3), 161-179. DOI: 10.1016/0031-9201(85)90127-x

Arena, A., Delle, P.C. and Sarout, J.: 2014, A new computational approach to cracks quantification from 2D image analysis: Application to micro-cracks description in rocks. Comput. Geosci., 66, 106-120. DOI: org/10.1016/j. cageo.2014. 01.007

Bauer, S.J. and Handin, J.: 1983, Thermal expansion and cracking of three confined water-saturated igneous rocks to $800{ }^{\circ} \mathrm{C}$. Rock. Mech Rock. Eng., 16(3), 181198. DOI: $10.1007 / \mathrm{BF} 01033279$

Colina, H. and Acker, P.: 2000, Drying cracks: Kinematics and scale laws. Mater Struct., 33(2), 101-107. DOI: $10.1007 / \mathrm{BF} 02484164$

David, C., Menendez, B. and Darot, M.: 1999, Influence of stress-induced and thermal cracking on physical properties and microstructure of La Peyratte granite. Int. J. Rock Mech. Min. Sci., 36(4), 433-448. DOI: 10.1016/S0148-9062(99)00010-8
Delle, P.C., Arena, A., Sarout, J., Esteban, L. and Cazes, E.: 2015, Micro-crack enhanced permeability in tight rocks: An experimental and microstructural study. Tectonophysics, $1-8$.

DOI: $10.1016 /$ j.tecto.2015.10.001

Demirdag, S.: 2013, Effects of freezing-thawing and thermal shock cycles on physical and mechanical properties of filled and unfilled travertine. Constr. Build. Mater., 47(5), 1395-1401.

DOI: 10.1016/j.conbuildmat.2013.06.045

Emirov, S.N. and Ramazanova, A.E.: 2013, Experimental study of heat transfer on the borders of grains in ordered and disordered media. B. Russ. Acad. Sci. Phys., 77(3), 284-287.

DOI: $10.3103 / \mathrm{S} 1062873813030106$

Fredrich, J.T. and Wong, T.: 1986, Micromechanics of thermally induced cracking in three crustal rocks. J. Geophys. Res., 91, 12743-12743. DOI: 10.1029/ JB091iB12p12743

Freire-Lista, D.M., Gomez-Villalba, L.S. and Rafael, F.: 2015, Microcracking of granite feldspar during thermal artificial processes. Period. Mineral, 84(3), 519-537. DOI: 10.2451/2015PM0029

Freire-Lista, D.M., Fort, R. and Varas, M.J.: 2016, Thermal stress-induced microcracking in building granite. Eng. Geol., 206, 83-93. DOI: 10.1016/j.enggeo. 2016. 03. 005

Gautam, P.K., Verma, A.K. and Jha, M.K. et al.: 2016, Study of strain rate and thermal damage of Dholpur sandstone at elevated temperature. Rock Mech. Rock Eng., 49(9), 1-11. DOI: 10.1007/s00603-016-0965-5

Ghassemt, A., Tarasovs, S. and Cheng, A.H.D.: 2007, A 3D study of the effects of thermomechanical loads on fracture slip in enhanced geothermal reservoirs. Int. J. Rock Mech. Min. Sci., 44(8), 1132-1148. DOI: $10.1016 / j$. .jrmms.2007.07.016

Gomez-Heras, M., Mccabe, S., Smith, B.J. et al.: 2009, Impacts of fire on stone-built heritage. J. Archit. Conserv., 15(2), 47-58.

DOI: 10.1080/13556207.2009.10785047

Griffiths, L., Heap, M.J., Baud, P., Schmittbuhl, J.: 2017, Quantification of microcrack characteristics and implications for stiffness and strength of granite. Int. J. Rock Mech. Min. Sci., 100, 138-150. DOI: $10.1016 / j$. .jrmms.2017.10.013

Hudson, J.A., Stephansson, O. and Jing, L. et al.: 2001, Coupled T-H-M issues relating to radioactive waste repository design and performance. Int. J. Rock Mech. Min. Sci., 38(1), 143-161.

DOI: 10.1016/ S1365-1609(00)00070-8.

Hale, P.A. and Shakoor, A.: 2003, A laboratory investigation of the effects of cyclic heating and cooling, wetting and drying, and freezing and thawing on the compressive strength of selected sandstones. Environ. Eng. Geosci., 9, 117-130.

Hall, K.: 1999, The role of thermal stress fatigue in the breakdown of rock in cold regions. Geomorphology, 31(1-4), 47-63. DOI: $10.1016 / \mathrm{S} 0169-555 \mathrm{X}(99)$ 00072-0.

Hall, K. and Thorn, E.: 2014, Thermal fatigue and thermal shock in bedrock: an attempt to un-ravel the geomorphic processes and products. Geomorphology, 206, 1-13.

DOI: 10.1016/j.geomorph.2013.09.022

Liu, S. and Xu, J.: 2014, Mechanical properties of Qinling biotite granite after high temperature treatment. Int. J. Rock Mech. Min. Sci., 71, 188-193. DOI: 10. 1016/j.ijrmms.2014.07.008

Mardoukhi, A., Mardoukhi, Y., Hokka, M. et al.: 2017, Effects of heat shock on the dynamic tensile behavior 
of granitic rocks. Rock Mech. Rock Eng., 50(5), 1171-1182. DOI: $10.1007 / \mathrm{s} 00603-017-1168-4$

Meredith, P.G., Knight, K.S., Boon, S.A. and Wood, I.G.: 2001, The microscopic origin of thermal cracking in rocks: An investigation by simultaneous time-of-flight neutron diffraction and acoustic emission monitoring. Geophys. Res. Lett., 28, 2105-2108.

DOI: $10.1029 / 2000$ GL012470

Murru, A., Freire-Lista, D.M., Fort, R., Varas-Muriel, M.J. and Meloni, P.: 2018, Evaluation of Post-thermal shock effects in Carrara Marble and Santa Caterina di Pittinuri limestone. Constr. Build. Mater., 186, 12001211.

Nasseri, M.H.B., Schubnel, A. and Young, R.P.: 2007, Coupled evolutions of fracture toughness and elastic wave velocities at high crack density in thermally treated westerly granite. Int. J. Rock Mech. Min. Sci., 44(4), 601-616. DOI: 10.1016/ j.ijrmms.2006.09.008

Nasseri, M.H.B., Tatone, B.S.A. and Grasselli, G.: 2009, Fracture toughness and fracture roughness interrelationship in thermally treated Westerly Granite. Pure. Appl. Geophys., 166(5-7), 801-822. DOI: $10.1007 /$ s00024-009-0476-3

Ogino, F., Yamamura, M. and Fukuda, T.: 1999, Heat transfer from hot dry rock to water flowing through a circular fracture. Geothermics, 28(1), 21-44. DOI: 10.1016 /S0375-6505(98)00043-1.

Ozguven, A. and Ozcelik, Y.: 2013, Investigation of some property changes of natural building stones exposed to fire and high heat. Constr. Build. Mater., 38(2), 813821. DOI: 10.1016/ j.conbuildmat.2012.09.072

Pearson, C.F., Fehler, M.C. and Albright, J.N.: 1983, Changes in compressional and shear-wave velocities and dynamic moduli during operation of a hot dry rock geothermal system. J. Geophys. Res., Solid. Earth, 88(4), 3468-3475. DOI: $10.1029 / \mathrm{JB} 088 \mathrm{iB} 04 \mathrm{p} 03468$

Rickard, H.: 2019, Fire behaviour of multiple fires in a mine drift with longitudinal ventilation. Int. J. Min. Sci. Technol., 29(02), 98-107. DOI: CNKI:SUN:ZHKD.0.2019-02-010

Rutqvist, J., Tsang, C. and Tsang, Y. et al.: 2005, Coupled thermal-hydrological-mechanical analyses of the Yucca Mountain Drift Scale Test - Comparison of field measurements to predictions of four different numerical models. Int. J. Rock Mech. Min. Sci., 42(5), 680-697. DOI: 10.1016/j.ijrmms.2005.03.008

Shafiei, A. and Dusseault, M.B.: 2013, Geomechanics of thermal viscous oil production in sandstones. J. Petrol. Sci. Eng., 103, 121-139. DOI: $10.1016 /$ j.petrol. 2013.02.001

Smith, A.G. and Pells, P.J.N.: 2008, Impact of fire on tunnels in Hawkesbury sandstone. Tunn. Undergr. Space. Technol. Incorporating. Trenchless. Technol. Res., 23(1), 65-74. DOI: 10.1016/j.tust.2006. 11.003

Somerton, W.H. and Boozer, G.D.: 1961, A method of measuring thermal diffusivities of rocks at elevated temperatures. AIChE J., 7(1), 87-90. DOI: 10.1002/aic.690070121

Sun, Q., Lü, C. and Cao, L. et al.: 2016, Thermal properties of sandstone after treatment at high temperature. Int. J. Rock Mech. Min. Sci., 85, 60-66. DOI: $10.1016 /$ j.ijrmms.2016.03.006

Sun, Q., Zhang, W. and Xue, L. et al.: 2015, Thermal damage pattern and thresholds of granite. Environ. Earth Sci., 74(3), 2341-2349. DOI: $10.1007 /$ s12665-015-4234-9

Tang, X., Wang, M. and Dong, C. et al.: 2016, Sensitivity analysis for shear strength of flat interface between shotcrete and granite in high temperature tunnel. Adv.
Eng. Res., 112, 155-160.

DOI: creativecommons.org/licenses/by-nc /4.0/

Underwood, E.E.: 1967, Quantitative Evaluation of Sectioned Material, in: Elias, H. (Ed.), Stereology. Springer Berlin Heidelberg, 49-60. DOI: $10.1007 / 978-3-642-88260-95$

Vasconcelos, G., Lourenço, P.B. and Costa, M.F.M.: 2008, Mode I Fracture surface of granite: measurements and correlations with mechanical properties. J. Mater. Civil. Eng., 20(3), 245-254. DOI: 10.1061/(ASCE)0899-1561(2008)20:3(245)

Vázquez, P., Shushakova, V. and Gómez-Heras, M.: 2015, Influence of mineralogy on granite decay induced by temperature increase: experimental observations and stress simulation. Eng. Geol., 189, 58-67. DOI: $10.1016 /$ j.enggeo.2015.01.026

Velde, B.: 1999, Structure of surface cracks in soil and muds. Geoderma, 93(1-2), 101-124.

DOI: S0016-7061 99 00047-6

Vogel, H.J., Hoffmann, H. and Leopold, A. et al.: 2005, Studies of crack dynamics in clay soil II. A physically based model for crack formation. Geoderma, 125(3), 213-223. DOI: 10.1016/j.geoderma.2004.07.008

Vogel, H.J., Hoffmann, H. and Roth, K.: 2005, Studies of crack dynamics in clay soil I. Experimental methods, results, and morphological quantification. Geoderma, 125(3), 203-211. DOI: 10.1016/j.geoderma.2004.07.009

Wang, C., Zhang, Z., Liu, Y. and Fan, S.: 2017, Geometric and fractal analysis of dynamic cracking patterns subjected to wetting-drying cycles. Soil Till. Res., 170, 1-13. DOI: org/10.1016/j.still.2017.02.005

Wang, L.L., Bornert, M. and Yang, D.S. et al.: 2015, Microstructural insight into the nonlinear swelling of argillaceous rocks. Eng. Geol., 193, 435-444. DOI: 10.1016/ j.enggeo.2015. 05.019

Yavuz, H.: 2011, Effect of freeze-thaw and thermal shock weathering on the physical and mechanical properties of an andesite stone. Bull. Eng. Geol. Environ., 70(2), 187-192. DOI: 10.1007/s10064-010-0302-2

Yoshitaka, N., Naoki, H. and Tetsuro, Y. et al.: 2010, Effects of relative humidity and temperature on subcritical crack growth in igneous rock. Int. J. Rock Mech. Min. Sci., 47(4), 640-646. DOI: $10.1016 / \mathrm{S} 1672-2515$ (07)60122-5

Zarichnyak, Y.P., Ramazanova, A.E. and Emirov, S.N.: 2013, Contribution of thermal radiation in measurements of thermal conductivity of sandstone. Phys. Solid State, 55(12), 2463-2441. DOI: $10.1134 / \mathrm{S} 1063783413120330$

Zhang, W., Sun, Q. and Hao, S. et al.: 2016, Experimental study on the variation of hysical and mechanical properties of rock after high temperature treatment. Appl. Therm. Eng., 98, 1297-1304. DOI: 10.1016/j.applthermaleng.2016. 01.010

Zhao, Y., Feng, Z. and Xi, B. et al.: 2011, Prospect of HDR geothermal energy exploitation in Yangbajing, Tibet, China, and experimental investigation of granite under high temperature and high pressure. J. Rock Mech. Geotech. Eng., 3(3), 260-269. DOI: 10.3724/ P.J.1235. 011.00260

Zhao, Z.H.: 2016, Thermal Influence on mechanical properties of granite: A microcracking perspective. Rock Mech. Rock Eng., 49, 747-762. DOI: $10.1007 / \mathrm{s} 00603-015-0767-1$

Zhu, T.T., Jing, H.W. and Su, H.J. et al.: 2016, Physical and mechanical properties of sandstone containing a single fissure after exposure to high temperatures. Int. J. Min. Sci. Technol., 26(02), 142-148. DOI: CNKI:SUN:ZHKD.0.2016-02-018 